\title{
ELECTRICAL PROPERTIES OF VARIOUS COMPOSITION OF YTTRIUM DOPED- ZIRCONIA PREPARED FROM LOCAL ZIRCON SAND
}

\author{
F. Rahmawati ${ }^{1 *}$, I. Permadani ${ }^{1}$, D.G. Syarif ${ }^{2}$, S. Soepriyanto ${ }^{3}$ \\ ${ }^{1}$ Research Group of Solid State Chemistry \& Catalysis, Chemistry Department, Sebelas Maret \\ University, Jl. Ir. Sutami 36A Kentingan, Surakarta 57126, Indonesia \\ ${ }^{2}$ Center of Science and Applied Nuclear Technology (PSTNT) BATAN, Jl. Taman Sari 73, Bandung, \\ Indonesia \\ ${ }^{3}$ Department of Metallurgy, Faculty of Mining and Petrochemical, Institut Teknologi Bandung, Jl. \\ Ganesha 10, Bandung, Indonesia
}

(Received: February 2017 / Revised: September 2017 / Accepted: October 2017)

\begin{abstract}
Doping yttrium ions, $\mathrm{Y}^{3+}$ into $\mathrm{ZrO}_{2}$ produced Yttria-Stabilized Zirconia, YSZ. Various amount of yttrium ions could provide different ionic conductivity. This research investigated electrical conductivity of various YSZ composition, i.e., 4.5; 8.0 and $10 \%$ mol yttrium in $\mathrm{ZrO}_{2}$. $\mathrm{The} \mathrm{ZrO}_{2}$ powder used was synthesized from zircon sand, a side product of tin mining plant, Bangka Island, Indonesia. Structural investigation on the prepared YSZ found that yttrium ion doping has changed the crystal structure of $\mathrm{ZrO}_{2}$ from monoclinic to cubic, even though the monoclinic and tetragonal are also still exist. The $\mathrm{Y}^{3+}$ doping changed the cell parameter of $\mathrm{ZrO}_{2}$ crystal. It indicates that the $\mathrm{Y}^{3+}$ entered into the $\mathrm{ZrO}_{2}$ structure and produced vacancy sites. The highest

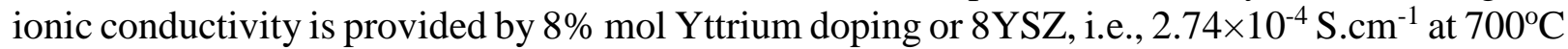
with an activation energy of $0.741 \mathrm{eV}$.
\end{abstract}

Keywords: Electrical conductivity; Various composition; YSZ; Zirconia; Zircon sand

\section{INTRODUCTION}

Indonesia has tin ore abundant spread over Pulau Karimun, Singkep, in some of the Sumatera lands, and also in Bangka Island, Riau islands, until to the West Kalimantan (Poernomo, 2012). Among of those, Bangka island has the largest Tin abundant with a side product is zircon sand $\left(\mathrm{ZrSiO}_{4}\right)$. Zircon, $\mathrm{ZrSiO}_{4}$, is a stable molecule due to the strong bond between zirconia and silica. Some methods to extract zirconium from zircon are caustic fusion or with soda ash (El-Barawy et al., 2000), heat plasma dissociation (Ananthapadmanabhan et al., 1993), thermal decomposition (Pavlik et al., 2001), caustic fusion (Rahmawati et al., 2016) and mechanochemical processing (Puclin et al., 1995).

Zirconia, $\mathrm{ZrO}_{2}$, is an important ceramics material due to its strengths and the high melting point temperature $\left(2700^{\circ} \mathrm{C}\right)$. In addition, zirconia also has oxygen ions conductivity, low thermal conductivity, high flexibility, and high corrosion resistance (Rivai \& Takahashi, 2010). Zirconia is used as a material for the oxygen sensor, fuel cell material, thermal barrier coating, and some high-temperature applications. Tetragonal zirconia has high mechanical strength; meanwhile, cubic zirconia has high ionic conductivity (Shackelford \& Doremus, 2008). The addition of some metal oxides such as $\mathrm{MnO}, \mathrm{NiO}, \mathrm{Cr}_{2} \mathrm{O}_{3}, \mathrm{Fe}_{2} \mathrm{O}_{3}, \mathrm{Y}_{2} \mathrm{O}_{3}$, and $\mathrm{Ce}_{2} \mathrm{O}_{3}$ could stabilize tetragonal

\footnotetext{
*Corresponding author's email: fitria@mipa.uns.ac.id, Tel: +62-71-646994, Fax: +62-71-646655 Permalink/DOI: https://doi.org/10.14716/ijtech.v8i5.876
} 
and cubic phase of zirconia at room temperature (Munggaran et al., 2014). Our previous research on preparing $\mathrm{ZrO}_{2}$ from Indonesian zircon sand found a $\mathrm{Zr}$ content of $72.1 \%$ and the presence of some impurities such as sodium oxide, $\mathrm{Na}_{2} \mathrm{O}$ at $14.71 \%$ and also silica, $\mathrm{SiO}_{2}$ at $3.03 \%$. The sodium oxide is known as the remains of sodium hydroxide reactant to mix with zircon, $\mathrm{ZrSiO}_{4}$, sand. Meanwhile, the silica content refers to the silica network in zircon sand as the raw material (Rahmawati et al., 2016).

A high ionic conductivity of the material is required to develop a solid oxide fuel cell, SOFC. Cubic zirconia is known to has highest ionic conductivity. However, the structure is not stable at room temperature. Doping of yttrium ions into zirconia is known to stabilize the cubic structure at room temperature and increase the ionic conductivity due to the formation of oxygen vacancies when $\mathrm{Zr}^{4+}$ is replaced by $\mathrm{Y}^{3+}$ (Shakthinathan et al., 2012). Low yttrium concentration might produce tetragonal zirconia that has good mechanical strength. Meanwhile, a high concentration of yttrium dopant might produce cubic structure zirconia that has high ionic conductivity (Shackelford \& Doremus, 2008). The ionic conductivity depends on the size and concentration of the dopant, in which yttria is the most common dopant for stabilizing the cubic phase of zirconia. When the $\mathrm{Y}_{2} \mathrm{O}_{3}$ content increases, the crystal structure of $\mathrm{ZrO}_{2}$ transforms from monoclinic to tetragonal and further transforms to the cubic phase when the yttria addition up to $8 \mathrm{~mol} \%$ (Sharma et al., 2016). When the $\mathrm{ZrO}_{2}$ is prepared from $\mathrm{ZrSiO}_{4}$ sand as a side product of tin mining plant, it is known that the addition of $\mathrm{Y}_{2} \mathrm{O}_{3}$ also transforms the structure to cubic, as confirmed by peaks at $2 \theta$ of $30.8^{\circ}, 34.92^{\circ}, 50.15^{\circ}$, and $59.52^{\circ}$ which are in agreement with the YSZ standard diffraction ICSD \#75316. However, the monoclinic $\mathrm{ZrO}_{2}$ still exists as small peaks at $2 \theta$ of $27.91^{\circ}$ and $31.09^{\circ}$, and tetragonal phase also present as small peaks at $2 \theta$ of $35.24^{\circ}$ and $60.26^{\circ}$ (Rahmawati et al., 2016).

The result is different when the commercial $\mathrm{ZrO}_{2}$ is used, in which doping of $>7 \mathrm{~mol}^{\%}$ produced the single cubic phase, while a $2-6 \mathrm{~mol} \% \mathrm{Y}_{2} \mathrm{O}_{3}$ content gives a partially stabilized (Sharma et al., 2016). Other researcher found $8-10 \mathrm{~mol} \% \mathrm{Y}_{2} \mathrm{O}_{3}$ that result in a fully cubic phase (Ochrombel et al., 2010). Meanwhile, for YSZ nanowire, the 4-10 mol\% $\mathrm{Y}_{2} \mathrm{O}_{3}$ doping level produces a dominated cubic phase (Liu et al., 2017). Crystal structure may affect the ionic conductivity. Meanwhile, because of the different purity grade, the similar amount of yttrium doping to $\mathrm{ZrO}_{2}$ that was prepared from Indonesian zircon sand and to the commercial $\mathrm{ZrO}_{2}$ may produce a different crystal structure. Therefore, this research investigates their electrical properties in accordance with the $\mathrm{Y}_{2} \mathrm{O}_{3}$ dopant amount. For the commercial grade zirconia, it is found that the highest conductivity level of $\left(\mathrm{ZrO}_{2}\right)_{1-\mathrm{x}}\left(\mathrm{Y}_{2} \mathrm{O}_{3}\right)_{\mathrm{x}}$ electrolyte is obtained when $x$ is 0.08 (Kharton et al., 1999). This research is going to understand if the $71.53 \pm 0.76 \%$ purity of $\mathrm{ZrO}_{2}$ and the presence of some impurities will affect the electrical conductivity as well.

\section{EXPERIMENTAL METHODS}

Yttrium stabilized-zirconia, YSZ, was prepared at the various composition of yttrium content, i.e., $4.5 \%, 8 \%$, and $10 \%$ mol. The yttrium dioxide, $\mathrm{Y}_{2} \mathrm{O}_{3}$, (Aldrich) was used as yttrium ions precursor. Meanwhile, $\mathrm{ZrO}_{2}$ was synthesized from Indonesian local zircon sand, procured as a side product of Tin Mining Plant in Bangka Island, Indonesia, and it was pre-concentrated in Laboratory of Metallurgy, Faculty of Mining and Oil Engineering, Institut Teknologi Bandung. $\mathrm{XRF}$ analysis on the zircon sand concentrate found that the concentrate consists of some elements, i.e., $\mathrm{Zr}, \mathrm{Si}, \mathrm{Na}, \mathrm{S}, \mathrm{Al}$ at $64.10 \%, 14.67 \%, 11.61 \%, 1.85 \%$, and $1.33 \%$, respectively, and some other small content elements at $6.44 \%$.

Zirconia, $\mathrm{ZrO}_{2}$ was synthesized by caustic fusion method (Soepriyanto et al., 2005; Rahmawati et al., 2012) in which the zircon sand concentrate, $\mathrm{ZrSiO}_{4}$, was crushed with $\mathrm{NaOH}$ at a ratio of $\mathrm{ZrSiO}_{4}: \mathrm{NaOH} 1: 4$. The mixture was then heated at $800^{\circ} \mathrm{C}$ to produce a greyish white powder. 
The powder then was leached with distilled water at a volume ratio of 1:10 of powder to water, and followed by filtration. Next step was to leach residue of filtration with $3.5 \mathrm{M}$ of $\mathrm{HCl}$ at a volume ratio of $1: 10$, means that 1 gram of residue was dissolved in $10 \mathrm{~mL} \mathrm{HCl}$, at $80^{\circ} \mathrm{C}$, and under stirred condition. The result was a cloudy yellow solution that produced a clear yellow solution after filtration. The yellow solution is $\mathrm{ZrOCl}_{2} \cdot 6 \mathrm{H}_{2} \mathrm{O}$ (ZOC). Zirconia, $\mathrm{ZrO}_{2}$, was precipitated from $\mathrm{ZOC}$ by slowly added $3 \mathrm{M}$ of $\mathrm{NH}_{4} \mathrm{OH}$. A white precipitate was produced. After decantation and heating at $800^{\circ} \mathrm{C}$ for 5 hours, a white powder of $\mathrm{ZrO}_{2}$ was founded. Our previous research on the caustic fusion of this Bangka Island zircon sand produced a zirconia powder at $71.53 \pm 0.76 \%$ of purity (Rahmawati et al., 2014).

Yttrium ions doping was conducted with $\mathrm{Y}_{2} \mathrm{O}_{3}$ as yttrium source. A mixture of $\mathrm{Y}_{2} \mathrm{O}_{3}$ and $\mathrm{ZrO}_{2}$ was crushed for 2 hours in a pestle at a stoichiometric ratio to produce a $4.5 \%, 8 \%$ and $10 \%$ mol of yttrium. Calcination was at $1000^{\circ} \mathrm{C}$ for 2 hours, then followed by sintering of its green pellets at $1500^{\circ} \mathrm{C}$ for 5 hours. X-ray diffraction analysis equipped with Le Bail refinement was used to identify the peaks in comparing with YSZ standard diffraction, and also to analyze its crystallinity, crystal structure, and its cell parameters. The prepared materials also were analyzed by SEM to understand their surface morphology. The MeasureIT software (free edition) was used to analyze the average particle size from SEM images. Meanwhile, the electrical conductivity was analyzed with LCR meter (GW Instek) to study their impedance plot and their electrical conductivity. The impedance was measured at $20-5 \mathrm{MHz}$ at $300-700^{\circ} \mathrm{C}$. The impedance curve was fitted with Origin 6.0 program (free edition), and the conductivity value was calculated by Equation 1.

$$
\kappa=\frac{1}{R} \frac{A}{l}
$$

where $\kappa$ is the specific conductivity $\left(\mathrm{Ohm}^{-1} . \mathrm{cm}\right)(\mathrm{S} . \mathrm{cm}), R$ is the resistance that was determined from impedance measurement equipped with the fitting process $(\mathrm{Ohm}), A$ is the area of the active electrode $\left(\mathrm{cm}^{2}\right)$, and $l$ is the thickness of material $(\mathrm{cm})$.

\section{RESULTS AND DISCUSSION}

The material characterization has been conducted on the prepared YSZ at $4.5 \%, 8 \%$, and $10 \%$ of mol yttrium ions. The analysis by X-ray diffraction equipped with le bail refinement and the results have been published in our previous paper (Rahmawati et al., 2016). The yttria-stabilized zirconia at $4.5 \%, 8 \%$, and $10 \%$ produced from zircon sand were crystallized in the same structure, i.e., cubic, tetragonal, and monoclinic with the space group of $F M 3 M, P 42 / N M C z$, and $P 1$ $21 / C$, respectively. The specific peaks of $\mathrm{ZrO}_{2}$ are identified at $2 \theta \sim 30.30^{\circ} ; 34.70^{\circ} ; 35.24^{\circ}$; $50.34^{\circ}$ and $60.26^{\circ}$. Meanwhile, a peak at $2 \theta \sim 28.36^{\circ}$ confirms the presence of monoclinic phase $\mathrm{ZrO}_{2}$ based on ICSD\#157403 (Rahmawati et al., 2016).

Impedance measurement at 20-5 MHz for 4.5 YSZ produce impedance curves as plotted in Figure 1. The Figure 1 shows that the impedance curve of $4.5 \mathrm{YSZ}$ is in a semicircle at 400, 500, 600 , and $700^{\circ} \mathrm{C}$. The impedance values decrease as the temperature increase. A similar trend also can be seen in Figure 2 for 8 YSZ, in which the impedance value decreases as the temperature increases. However, at $400^{\circ} \mathrm{C}$, the $8 \mathrm{YSZ}$ shows a two semicircle curve of impedance (Figure 2). Those two semicircle indicates that the ionic conductivity of 8 YSZ consists of grain conduction and grain boundary conduction ( $\mathrm{Li}$ et al., 2003). The impedance value of $8 \mathrm{YSZ}$ is lower at various temperature, in which at $600^{\circ} \mathrm{C}$ the impedance of $8 \mathrm{YSZ}$ is around $600 \mathrm{Ohm}$, which is 5 times lower of 4.5 YSZ impedance value. Meanwhile, the 10 YSZ shows a similar trend of impedance curve with $8 \mathrm{YSZ}$, in which at $400^{\circ} \mathrm{C}$ the impedance curve consists of two semicircles indicating grain and grain boundary conductivity. However, the impedance value of $10 \mathrm{YSZ}$ at various temperature are higher than the impedance of 8 YSZ. As it can be seen in Figure 3 that 
the impedance of $10 \mathrm{YSZ}$ at $600^{\circ} \mathrm{C}$ is around $3500 \mathrm{Ohm}$, meanwhile the impedance of $8 \mathrm{YSZ}$ is around $600 \mathrm{Ohm}$.

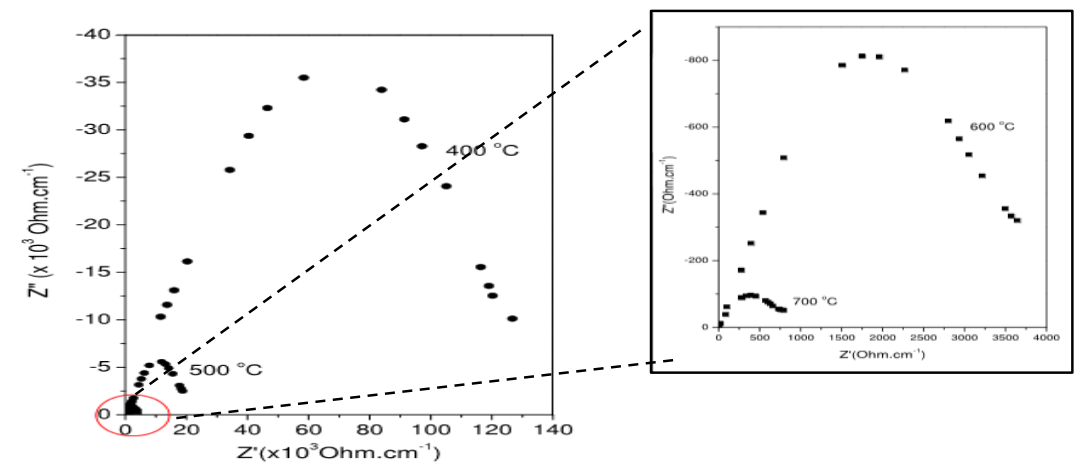

Figure 1 Nyquist plots of $4.5 \mathrm{YSZ}$ at $400^{\circ} \mathrm{C}, 500^{\circ} \mathrm{C}, 600^{\circ} \mathrm{C}$, and $700^{\circ} \mathrm{C}$

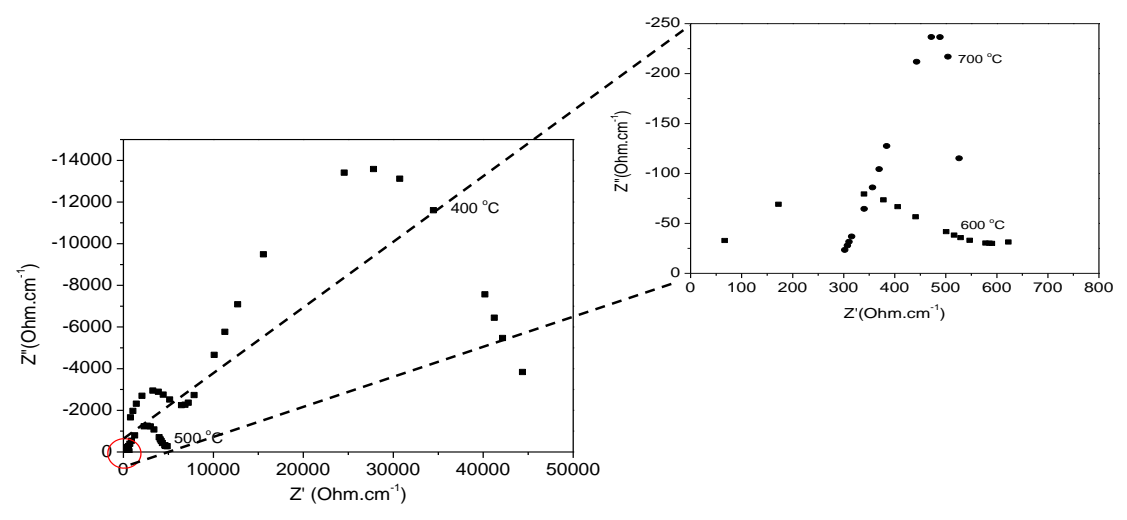

Figure 2 Nyquist plots of $8 \mathrm{YSZ}$ at $400^{\circ} \mathrm{C}, 500^{\circ} \mathrm{C}, 600^{\circ} \mathrm{C}$, and $700^{\circ} \mathrm{C}$

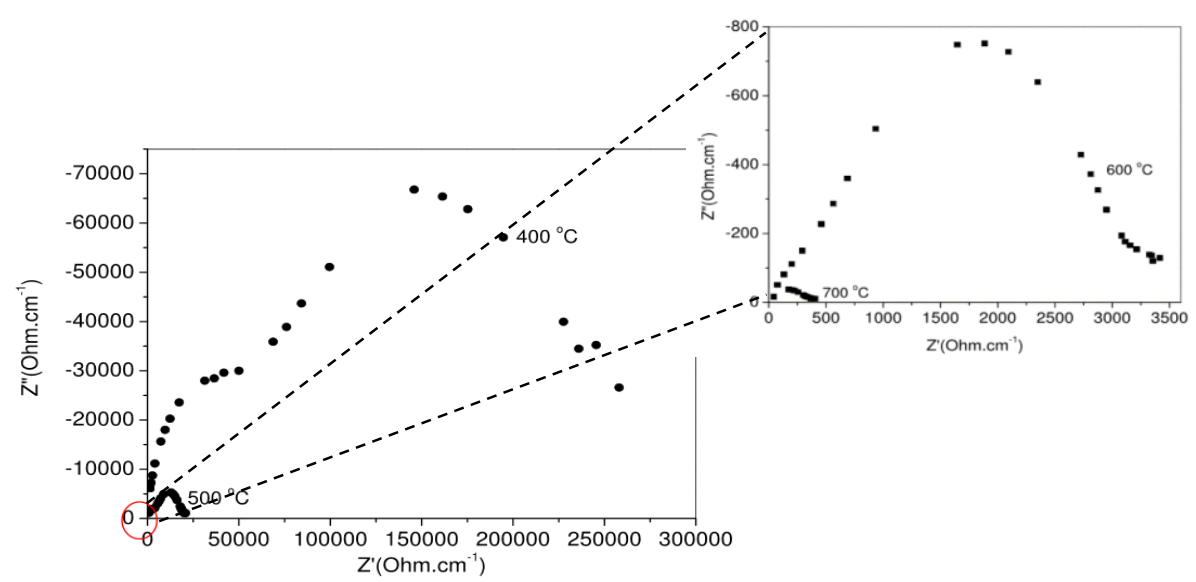

Figure 3 Nyquist plots of $10 \mathrm{YSZ}$ at $400^{\circ} \mathrm{C}, 500^{\circ} \mathrm{C}, 600^{\circ} \mathrm{C}$, and $700^{\circ} \mathrm{C}$

Curve analysis continued by conductivity calculation found that 8 YSZ has the highest conductivity (Table 1). This result is in agreement with the result on commercial zirconia, in which the highest conductivity also found at 8 YSZ (Ramamoorthy et al., 1999). Based on refinement result on X-ray diffraction data, it is known that the cell volume of a cubic phase of 8 
YSZ is highest than 4.5 YSZ and 10 YSZ. The cell volume of 8 YSZ is $137.551392 \AA^{3}$. Meanwhile, the cell volume of 4.5 YSZ and 10 YSZ are 135.408920 $\AA^{3}$ and $136.834610 \AA^{3}$, respectively. The diffraction data was refined successfully with the standard input data of ICSD\#75316, a cubic zirconia with a space group of $F m 3 m$. A high cell volume may allow oxygen ions to migrate easier than in a small cell volume crystal structure. The ionic conductivity also in correlation with the porosity of the sintered material, in which high porosity of material can cause low ionic migration due to losing contact between grains. Therefore it will require a higher temperature to move the ions between grains (Munggaran et al., 2014).

Morphological analysis by scanning electron microscope on the various composition of YSZ found that the grain size of $8 \mathrm{YSZ}$ is $2.021 \pm 0.716 \mu \mathrm{m}$, which is larger than the grain size of 10 YSZ, i.e., $1.529 \pm 0.498 \mu \mathrm{m}$ with more pores existed inside, as it can be recognized in SEM image as the dark holes (Rahmawati et al., 2016). SEM images of the prepared materials and its magnification (30\% magnification) are depicted in Figure 4.
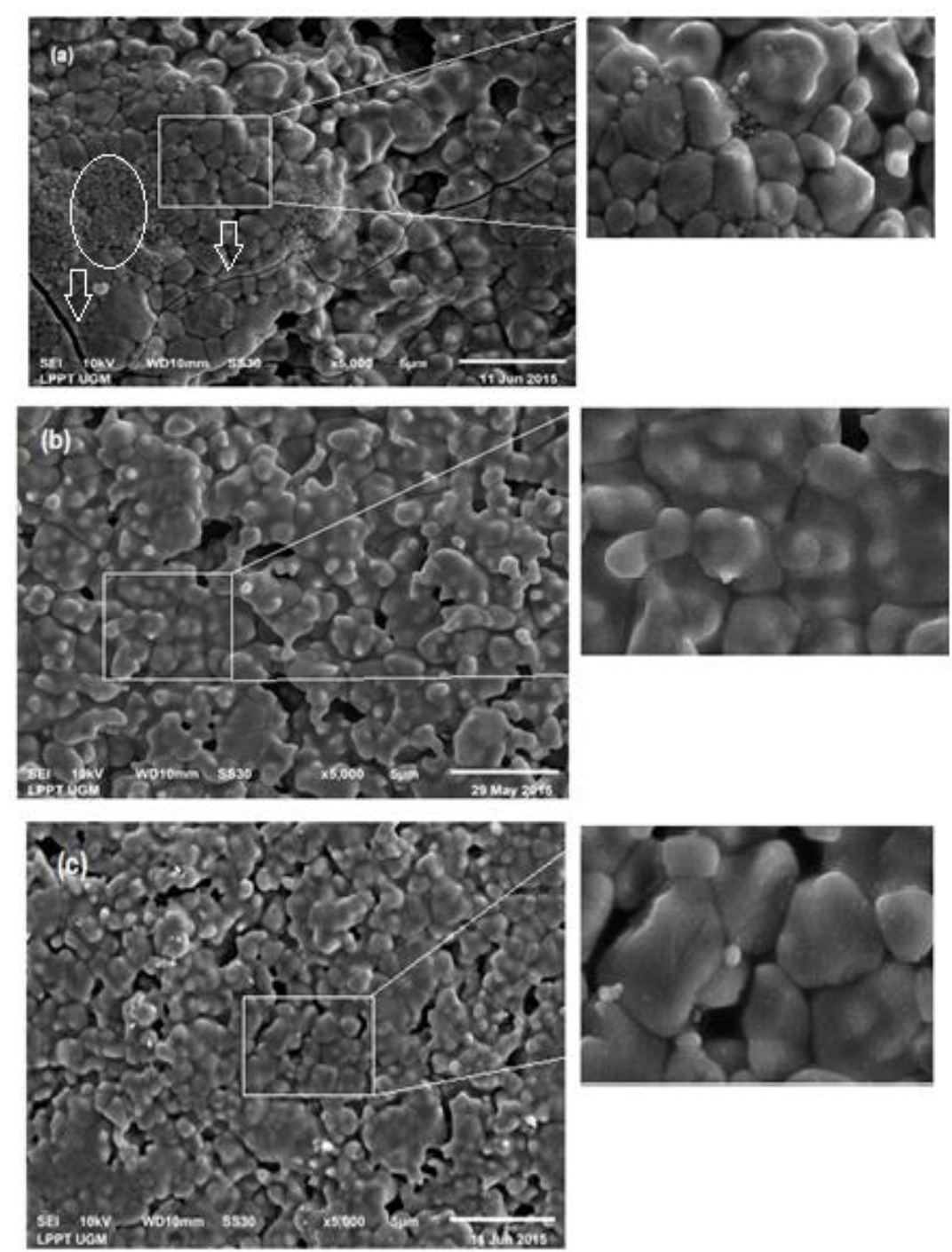

Figure 4 SEM images of $4.5 \mathrm{YSZ}$, the white circle is showing a blocking phase, and the white arrows are showing the crack lines (a), 8 YSZ (b), and 10 YSZ (c) and each 30\% magnification

The morphology of 4.5 YSZ shows a heterogeneous surface with the presence of blocking phase as it is described in Figure 4. The blocking phase was also found when zirconia from zircon sand was combined with lanthanum gallate material, i.e., $\mathrm{La}_{0.8} \mathrm{Sr}_{0.2} \mathrm{Ga}_{0.8} \mathrm{Mg}_{0.2} \mathrm{O}_{2-\delta}$ (Rahmawati et al., 
2012). The elemental analysis on the blocking point of 4.5 YSZ found that the blocking phase is a silica-rich phase, with $3.03 \%$ of silica content and $14.71 \%$ of sodium oxide. The sodium content might come from $\mathrm{NaOH}$ as destructive chemical. However, those sodium content would release when the material was heated at $1500^{\circ} \mathrm{C}$ for 5 hours during the sintering process. Liu et al. (2014) also found such impurities when producing zirconia from Brazillian zircon. The sodium silicate is formed during mixing process between zircon sand and $\mathrm{NaOH}$, and it hydrolized into $\mathrm{H}_{2} \mathrm{SiO}_{3}$ during water leaching. The $\mathrm{Na}_{2} \mathrm{ZrSiO}_{5}$ is also might produce during the caustic fusion process, which then reacts with $\mathrm{HCl}$ during acid leaching to produce $\mathrm{ZrO}(\mathrm{OH})_{2}-\mathrm{SiO}_{2}$ and $\mathrm{NaCl} \cdot \mathrm{ZrO}(\mathrm{OH})_{2}$. As the final result, the composition of powder produced from Brazillian zircon sand are $\mathrm{ZrO}_{2}$, $\mathrm{SiO}_{2}$, and $\mathrm{Na}_{2} \mathrm{O}$ were $57.169 \%, 6.77 \%$ and $7.049 \%$, respectively (Liu et al., 2014). The nonhomogeneous content also caused a crack line in the $4.5 \mathrm{YSZ}$ pellet after sintering at $1500^{\circ} \mathrm{C}$ for 5 hours. The crack line (Figure 4) causes a loose contact between grains allowing high ionic migration resistant and low ionic conductivity.

Table 1 Conductivity of the various YSZ composition at various temperature

\begin{tabular}{ccc}
\hline Materials & Temperature $\left({ }^{\circ} \mathrm{C}\right)$ & Conductivity $\left({\left.\mathrm{S} . \mathrm{cm}^{-1}\right)}^{-}\right.$ \\
\hline & 300 & $1.95 \times 10^{-7}$ \\
$4.5 \mathrm{YSZ}$ & 400 & $2.96 \times 10^{-6}$ \\
& 500 & $1.03 \times 10^{-5}$ \\
& 600 & $8.84 \times 10^{-5}$ \\
& 700 & $2.24 \times 10^{-4}$ \\
\hline & 300 & $3.14 \times 10^{-7}$ \\
& 400 & $5.76 \times 10^{-6}$ \\
& 500 & $5.86 \times 10^{-6}$ \\
& 600 & $4.55 \times 10^{-5}$ \\
& 700 & $2.74 \times 10^{-4}$ \\
\hline & 300 & $2.21 \times 10^{-8}$ \\
& 400 & $2.40 \times 10^{-6}$ \\
& 500 & $1.70 \times 10^{-5}$ \\
& 600 & $1.67 \times 10^{-5}$ \\
& 700 & $1.98 \times 10^{-4}$ \\
\hline
\end{tabular}

The Arrhenius plot between the specific conductivity and reverse of temperature can be used to determine the activation energy, Ea, of ionic migration (Figure 5). The Arrhenius equation is described in Equation 2 (Zhang et al., 2007).

$$
\sigma T=\sigma_{o} \exp \left(\frac{-E a}{k T}\right)
$$

where $E a$ is the activation energy for ionic conduction, $\sigma$ is the ionic conductivity, $\sigma_{0}$ is the preexponential factor, $k$ is the Boltzmann constant, and $T$ is the temperature. The slope of linear regression line representing $\left(-\frac{E a}{k T}\right)$, by input the temperature and the Boltzmann constant, the value of $E_{a}$ can be determined. The result is listed in Table 2, in which the activation energy of 8 YSZ is the lowest, i.e., $0.741 \mathrm{eV}$. It indicates that the ionic migration in $8 \mathrm{YSZ}$ could proceed easier than in 4.5 YSZ and in $10 \mathrm{YSZ}$. The physical properties regarding the inter-grains connection and the cell volume might become the factors related to that ionic migration. 


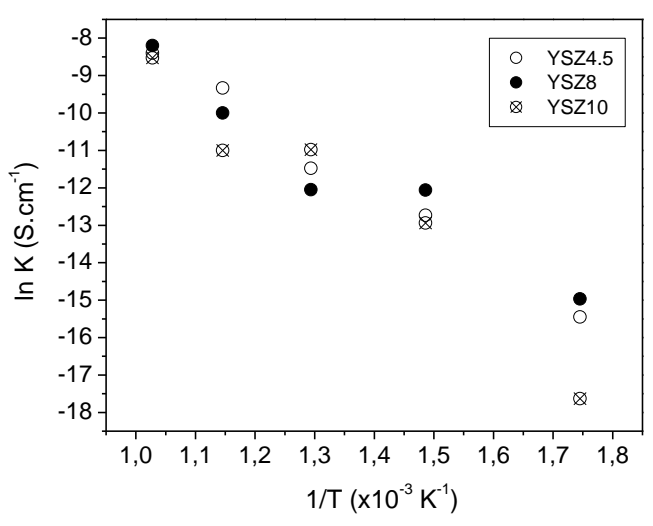

Figure 5 The Arrhenius plot of 4.5 YSZ, 8 YSZ, and 10 YSZ

Table 2 Activation energy, $E a$, pre-exponential factor and regression coefficient of 4.5 YSZ, 8 YSZ and 10 YSZ

\begin{tabular}{ccc}
\hline \multirow{2}{*}{ Materials } & Activation Energy, Ea (eV) & Coef.of regression, \\
& & $\mathrm{R}^{2}$ \\
\hline $4.5 \mathrm{YSZ}$ & 0.846 & 0.991 \\
$8 \mathrm{YSZ}$ & 0.741 & 0.932 \\
$10 \mathrm{YSZ}$ & 0.999 & 0.935 \\
\hline
\end{tabular}

\section{CONCLUSION}

The yttria-stabilized zirconia at $4.5 \%, 8 \%$, and $10 \%$ produced from zircon sand were crystallized in the same structure, i.e., cubic, tetragonal, and monoclinic with the space group of $F M 3 M, P$ $42 / N M C z$, and $P 121 / C 1$, respectively. The yttrium ion doping changed the cell parameter of $\mathrm{ZrO}_{2}$. The highest ionic conductivity is provided by $8 \mathrm{~mol} \%$ Yttrium doping or 8 YSZ, i.e., 2.74 $\mathrm{x} 10^{-4} \mathrm{~S} . \mathrm{cm}^{-1}$ at $700{ }^{\circ} \mathrm{C}$ with an activation energy of $0.741 \mathrm{eV}$. The activation energy is the lowest among the produced YSZ. It indicates that the ionic migration in $8 Y S Z$ could proceed easier than in 4.5YSZ and in 10YSZ.

\section{ACKNOWLEDGMENT}

This research is a part of INSINAS Ristek Project which was funded by The Ministry of Research, Technology, and Higher Education, Republic of Indonesia, contract No. 147/M/Kp/IV/2015. Authors acknowledge the funding support.

\section{REFERENCES}

Ananthapadmanabhan, P.V., Sreekumar, K.P., Iyer, K.V., Venkatramani, N., 1993. Plasma Dissociation of Indian Zircon. Journal of Alloys and Compounds, Volume 196(1-2), pp. 251-254

El-Barawy, K.A., El Tawil S.Z., Francis A.A., 2000. Alkali Fusion of Zircon Sand. Transaction of the Institute of Mining and Metallurgical Sect. C, Volume 109(1), pp. C49-C56

Kharton, V.V., Naumovich, E.N., Vecher, A.A., 1999. Research on the Electrochemistry of Oxygen Ion Conductors in the Former Soviet Union. I. $\mathrm{ZrO}_{2}$-based Ceramic Materials. Journal of Solid State Electrochemistry, Volume 3(2), pp. 61-81 
Li, Y., Liu, M., Gong, J.H., Chen, Y., Tang, Z.L., Zhang, Z.T., 2003. Grain Boundary Effect in Zirconia Stabilized with Yttria and Calcia by Electrical Measurements. Material Science Engineering B, Volume 103(2), pp. 108-114

Liu, R., Qu, J., Song, J., Qi, T., Du, A., 2014. Analysis of Water Leaching and Transition Processes in Zirconia Oxychloride Octahydrate Production. Ceramics International, Volume 40(1), pp. 1431-1438

Liu, W., Ou, G., Yao, L., Nishijima, H., Pan, W., 2017. Enhanced Ionic Conductivity in Phase Stabilized Yttria-doped Zirconia Nanowires. Solid State Ionics, Volume 380, pp. 34-39

Munggaran, G., Fitriyani, D., Rivai, A.K., 2014. Sintesis Bahan YSZ dengan Metode Reaksi Padatan dan Karakterisasinya. Jurnal Universitas Andalas, Volume 3(2), pp. 102-108

Ochrombel, R., Schneider, J., Holdmann, B., Saruhan, B., 2010. Thermal Expansion of EB-PVD Yttria Stabilized Zirconia. Journal of European Ceramic Society, Volume 30(12), pp. 2491-2496

Pavlik, R.S., Holland, H.J., Payzant, E.A., 2001. Thermal Decomposition of Zircon Refractories. Journal of the American Ceramic Society, Volume 84(12), pp. 2930-2936

Poernomo, H., 2012, Informasi Umum Zirkonia. Badan Tenaga Nuklir Nasional Pusat Teknologi Akselerator dan Proses Bahan, Yogyakarta

Puclin, T., Kaczmarek, W.A., Ninham, B.W., 1995, Mechanochemical Processing of $\mathrm{ZrSiO}_{4}$. Materials Chemistry and Physics, Volume 40(2), pp. 73-81

Rahmawati, F., Prijamboedi, B., Soepriyanto, S., Ismunandar, 2012. SOFC Composite Electrolyte based on LSGM-8282 and Zirconia or Doped Zirconia from Zircon Concentrate. International Journal of Minerals, Metallurgy and Materials, Volume 19(9), pp. 861-871

Rahmawati, F., Permadani, I., Soepriyanto, S., Syarif, D.G., Heraldy, E., 2014. Double Step Leaching and Filtration in Caustic Fusion Method to Produce Zirconia from Local Zircon Concentrate. In: The $7^{\text {th }}$ International Conference on Physics and Its Applications 2014 (ICOPIA 2014), Atlantis Press, pp. 99-102

Rahmawati, F., Permadani, I., Heraldy, E., Syarif, D.G., Soepriyanto, S., 2016. Structure and Morphological Analysis of the Various Composition of Yttrium Doped-zirconia Prepared from Local Zircon Sand. IOP Journal of Physics: Conference Series, Volume 776(1), pp.1-6

Ramamoorthy, R., Sundararaman, D., Ramasamy, S., 1999. Ionic Conductivity Studies of Ultrafine-grained Yttria Stabilized Zirconia Polymorphs. Solid State Ionic, Volume 123(14), pp. 271-278

Rivai, A.K., Takahashi, M., 2010. Investigation of a Zirconia Solid Electrolyte Oxygen Sensor in the Liquid Lead. Journal of Nuclear Materials, Volume 398(1-3), pp. 160-165

Shackelford, J.F., Doremus, R.H., 2008. Ceramic and Glass Materials Structure, Properties and Processing, Springer, New York

Shakthinathan, G., Raju, S., Chandrasekaren, U., 2012. Thermal Characteristic of Yttriastabilized Zirconia Nano Lubricants. Thermal Science, Volume 16(2), pp. 481-487

Sharma P., Singh K L., Singh A P., 2016, A study on the present status of zirconia based electrolytes for solid oxide fuel cell, Research \& Reviews: Journal of Pure and Applied Physics, volume 4 (3), pp. 23-26

Soepriyanto, S., Korda, A.A., Hidayat, T., 2005. Development of Zircon Base Industrial Product from a Zircon-sand Concentrate of Bangka Tin Processing. In: Proceeding of the $3^{\text {rd }}$ International Workshop on Earth Science and Technology, Fukuoka, Japan

Zhang, C., Li, C.-J., Zhang, G., Ning, X.-J., Li, C.-X., Liao, H., Coddet, C., 2007. Ionic Conductivity and Its Temperature Dependence of Atmospheric Plasma-sprayed Yttria Stabilized Zirconia Electrolyte. Materials Science and Engineering B, Volume 137(1-3), pp. 24-30 